\title{
Water Management System Based on Zero Run Off Policy in Multi Unit Area (Case Study of Menara Asuransi Astra In Cilandak, South Jakarta, Indonesia)
}

\author{
Lailatul Mukarromah ${ }^{1,2}$, Ussy Andawayanti ${ }^{3}$, Tri Budi Prayogo ${ }^{3}$ \\ ${ }^{1}$ Master Degree of Water Resources Engineering, Brawijaya University Malang, \\ Indonesia \\ ${ }^{2}$ Investment and One Stop Services Board, Jakarta, Indonesia \\ ${ }^{3}$ Water Resources Engineering Program, Brawijaya University Malang, Indonesia \\ lala_vlo@yahoo.com
}

Received 07-02-2018; revised 07-03-2018; accepted 20-03-2018

\begin{abstract}
Water system management is an effort of planning, management, control, and supervision of runoff water that is structured and integrated in an area according with the policies. In Governor Regulation of Jakarta Capital City Administration No. 43 of 2013 on the Peil of Building Floor Licence, it is explained that the implementation of the zero Delta Q principle is to keep the runoff remain in the area up to $100 \%$ / zero runoff. This research is expected to develop a concept of a regional water system implementation which compares the hydrological analysis method with related regulatory methods, to obtain a technical policy that can be applied in order to meet the regional regulations based on the zero delta Q concept for all to be developed areas in Jakarta (South Jakarta area as a pilot project). The conclusion is the calculation by hydrological analysis in accordance with the Indonesian National Standard Regulation (SNI) No. 0324532002 on the Procedure of Planning Technique of Rainwater Recharge wells for Grounds becomes the chosen method, because it has a more detailed result and zero runoff concept can be met, so the runoff at the study site did not increase the load of Grogol River.
\end{abstract}

Keywords: Water system management, zero delta Q, zero runoff, recharge wells.

\section{Introduction}

Increased development, accumulation of activities, and increasing population in the Jakarta resulted in increasing space cover and the decreasing of open space as a retention area. Increased development such as settlements, office buildings, hotels, shops, business centers, hospitals, schools, roads, and other facilities are reduce open space rapidly. The built space proportion in South Jakarta is $\pm 77.65 \%$, while the built space of Central Jakarta, West Jakarta and East Jakarta are respectively $\pm 72.55 \%, 66.09 \%, 66,77 \%$. The amount of built space causes the rain that fell to the surface directly becomes rainfall runoff. In the 10-year repatriation period, the runoff contribution from South Jakarta is $\pm 30.59 \%$, East Jakarta $\pm 30.22 \%$, West Jakarta $\pm 18.49 \%$, and Central Jakarta $\pm 8.64 \%$ (Technical Data of Department of Water Resources of Jakarta Capital City Administration, 2015). 
Water system management is a planning effort, management, control, and supervision of runoff water that is structured and integrated in the regional area in accordance with the policies. According to Governor Regulation of Jakarta Capital City Administration No. 43 of 2013 on the Peil of Building Floor Licence, the Delta Q zero principle is implemented by holding the runoff remains in the area up to $100 \%$ or drain the water out of the area to zero percent or zero runoff.

According to Governor Regulation of Jakarta Capital City Administration No. 20 of 2013 about recharge wells, the effort to utilize rainwater, reduce water runoff and conserve groundwater is by creating recharge wells and shelters that serve as a space to accommodate, store, and absorb rainwater that can increase the groundwater content. The increasing amount of building construction either above or below the ground has reduce the rainwater infiltration into the soil and the aquifer volume that can lead to floods and droughts.

At the study site, rainfall runoff still occurs due to poorly functioning conservation building , where the runoff flow is directly directed to Grogol River due to the contours of the study sites that directly lead to Grogol River. Therefore, a system support and drainage technology of the buildings, plots, and areas are necessary in order to generate a better zero runoff concept that can discharge runoff out of the area (Grogol River) as low as possible or even zero runoff.

The objective of the research is to generate a regional water system application concept that compares the hydrological analysis method with the relevant regulatory method, to obtain a technical policy that can be applied to meet the regulations based on the concept of zero delta $\mathrm{Q}$ or zero runoff for all regions which will be developed in Jakarta Capital City Administration, especially South Jakarta.

The expected benefits of the research results are to create a water management system concept that can be used as technical guidance for the owner of the activity or community in building a premise based on zero runoff policy in Jakarta Capital City Administration, especially South Jakarta.

\section{Material and Methods}

\subsection{Case Study Area}

Building Name : Office, Shelter, and Facilities

Building Number : 4 (Four) Building Units

Building Location : Jl. TB. Simatupang kavling 15, Kelurahan Lebak Bulus Kecamatan Cilandak, Jakarta Selatan

Building Use : Office, Trade, and Service

Total Area $\quad: 23.530 \mathrm{~m}^{2}$

Development Area $\quad: 10.9619 \mathrm{~m}^{2}$

- Roof Covered Area : 6.203,86 $\mathrm{m}^{2}$

- Pavement Area : : 4.415,14 $\mathrm{m}^{2}$

Existing Area $\quad: 12.911 \mathrm{~m}^{2}$

- Roof Covered Area : 5.532,97 $\mathrm{m}^{2}$

- Pavement Area : : 4.415,14 $\mathrm{m}^{2}$

- Open Space Area $\quad: 2.911 \mathrm{~m}^{2}$ peil).

The highest river water level from the road is $+32,072 \mathrm{~m}$ (pp) (data measuring from the existing Groundwater level is $3.06 \mathrm{~m}$ (borlog result).

\subsection{Calculation of Conservation building Based on Hydrological Calculations and Indonesian National Standard Regulation (SNI) No. 03-2453-2002}

In this research, three kinds of calculation alternatives are conducted in determining the amount of runoff that occurred at the study location and system management to meet the zero runoff.

A. Alternative I : The design discharge calculation with a return period 5th year in which all discharged at the study site is accommodated by the recharge well and the remainder is directed to 
a recharge pond, assuming that land cover/soil surface is considered equal with urban business area.

B. Alternative II : The design discharge calculation with a return period 5th year considering the type of land cover/ soil surface in the C calculation. The discharged entering the recharge well is only derived from the gutter/ building roof, while the runoff discharge in other land cover goes into the recharge pond through the internal drain.

C. Alternative III : The design discharge calculation with a return period 5th year considering the types of every land covers/ soil surface in the $\mathrm{C}$ calculation. The discharged from the gutter/ building roof enters the injection well, while the runoff of other land cover goes into the retention pond through the internal drain.

D. From the three alternatives (A), (B), (C) then a comparison is conducted with the calculation analysis according to the Governor Regulation of Jakarta Capital City Administration about the zero runoff policies..

\section{Result and Discussion}

A. Hydrological analysis calculation and Indonesian National Standard Regulation (SNI) No. 032453-2002 resulted in 3 (three) alternatives of water system management with conservation building plan:

Alternative I :

Recharge well :

Diameter $3 \mathrm{~m}$ and depth $3 \mathrm{~m}$

Recharge well capacity $466,71 \mathrm{~m}^{3}$.

Number of planned recharge wells: 22 units

Recharge period : 4,23 days per well

Retention pond (RP):

Retention pond dimension

RP I : $9 \mathrm{~m} \times 14 \mathrm{~m} \times 2 \mathrm{~m}$

RP II $\quad: 8 \mathrm{~m} \times 14 \mathrm{~m} \times 2 \mathrm{~m}$

Retention pond capacity $455,5 \mathrm{~m}^{3}$.

Retention period: 4,23 hari

Total recharge capacity : $922,21 \mathrm{~m}^{3}$.

Total open space area for conservation building : $317,40 \mathrm{~m}^{2}$.

Cost estimate for zero runoff concept : IDR. 689.503.000,-.

Implementation on the field : Not implementable.

\section{Alternatif II :}

Recharge well :

Diameter $3 \mathrm{~m}$ and depth $3 \mathrm{~m}$

Recharge well capacity $459,49 \mathrm{~m}^{3}$.

Number of planned recharge wells : 22 units

Retention pond (RP) :

RP I $\quad: 8 \mathrm{~m} \times 12 \mathrm{~m} \times 2 \mathrm{~m}$

RP II : $8 \mathrm{~m} \times 13 \mathrm{~m} \times 2 \mathrm{~m}$

Retention pond capacity $394,63 \mathrm{~m}^{3}$.

Total recharge capacity : $854,12 \mathrm{~m}^{3}$.

Total open space area for conservation building : $294,71 \mathrm{~m}^{2}$.

Cost estimate for zero runoff concept : IDR. 674.631.000,--

Implementation on the field : implementable.

\section{Alternatif III :}

Deep recharge well/injection well:

Injection well dimension (diameter $0,08 \mathrm{~m} \times$ depth $13 \mathrm{~m}$ )

Number of well : 4 unit with total capacity $541,23 \mathrm{~m}^{3}$. 
Retention pond (RP) :

RP I : $12 \mathrm{~m} \times 12 \mathrm{~m} \times 3 \mathrm{~m}$

RP II : $11 \mathrm{~m} \times 21,2 \mathrm{~m} \times 2 \mathrm{~m}$

Retention pond capacity $394,63 \mathrm{~m}^{3}$.

Total recharge capacity : $935,85 \mathrm{~m}^{3}$.

Total open space area for conservation building : 139,54 $\mathrm{m}^{2}$.

Cost estimate for zero runoff concept : IDR. 646.021.000,-.

Implementation on the field : implementable.

B. Calculation based on Governor Regulation of Jakarta Capital City Administration in conservation building resulted below:

- Total recharge volume : $978 \mathrm{~m}^{3}$.

- 22 units of recharge well (diameter $3 \mathrm{~m} \times$ depth $3 \mathrm{~m}$ ) with total capacity $487,9 \mathrm{~m}^{3}$.

- 1 unit of detention pond $(8 \mathrm{~m} \times 8 \mathrm{~m} \mathrm{x} 2 \mathrm{~m})$ with total capacity $132,06 \mathrm{~m}^{3}$.

- Retention pond (15m x 15,7m x 1,5m) with total capacity $375,65 \mathrm{~m}^{3}$.

- Total open space area for conservation building : 489,23 m2

- Cost estimate for zero runoff concept : IDR. 666.434.000,--

- Implementation on the field : implementable.

C. Calculation results comparison based on Governor Regulation and hydrological result analysis and Indonesian National Standard Regulation (SNI) No. 03-2453-2002.

The three alternative calculation results with hydrological method and the Indonesian National

Standard Regulation (SNI) No. 03-2453-2002 then compared with the calculation written in Governor Regulation. The result of Governor Regulation calculation is:

- Type of calculation, structure, and soil permeability coefficients value are not discussed.

- The calculation is only based on the roof covered area, while the runoff of other land cover areas such as paving surface, road, garden is not calculated

- Retention pond obligation is only for land with area of $\geq 5,000 \mathrm{~m}^{2}$.

- Allocation of conservation building (retention ponds, recharge wells, water reservoirs) is not based on elevation/ land contour of the premises.

- Overflow from the recharge well is still directed into the drainage channel.

- No calculation of the time soil takes to absorb water stored in the conservation building.

- The total of recharge volume is $1,078 \mathrm{~m}^{3}$.

- The value and certainty of zero runoff compliance is not measurable and not specified.

- The calculation is not based on the rework, but when compared with the return period on the hydrological analysis, it is in accordance with the return period 5th year.

- Need more budget and open space area for conservation building.

While the results of hydrological calculation and Indonesian National Standard Regulation (SNI) No. 03-2453-2002 is:

- Type of calculation, structure, and soil permeability coefficients value are discussed.

- The runoff calculation is based on all covered area, including roof, paving surface, road, garden by calculating the different surface cover coefficient (C) factors.

- Calculation and establishment of conservation building needs is based on total runoff of land area, not just a specific land area.

- Allocation of buildings conservation (retention ponds, recharge wells, detention ponds) is based on elevation/ land contour of the premises.

- Zero runoff compliance is completely calculated, so no runoff exits the premises, and zero run off can be achieved.

- The time soil takes to absorb the water contained in the conservation building is calculated, so the recharge well age can be monitored if the water is saturated.

- The total of recharge volume is $854,12 \mathrm{~m}^{3}$. 
- Calculations are taken for return period 5th year, assuming the greatest risk level and the flood discharge possibility are based on the current precipitation.

- Lower budget and less open space area for conservation building.

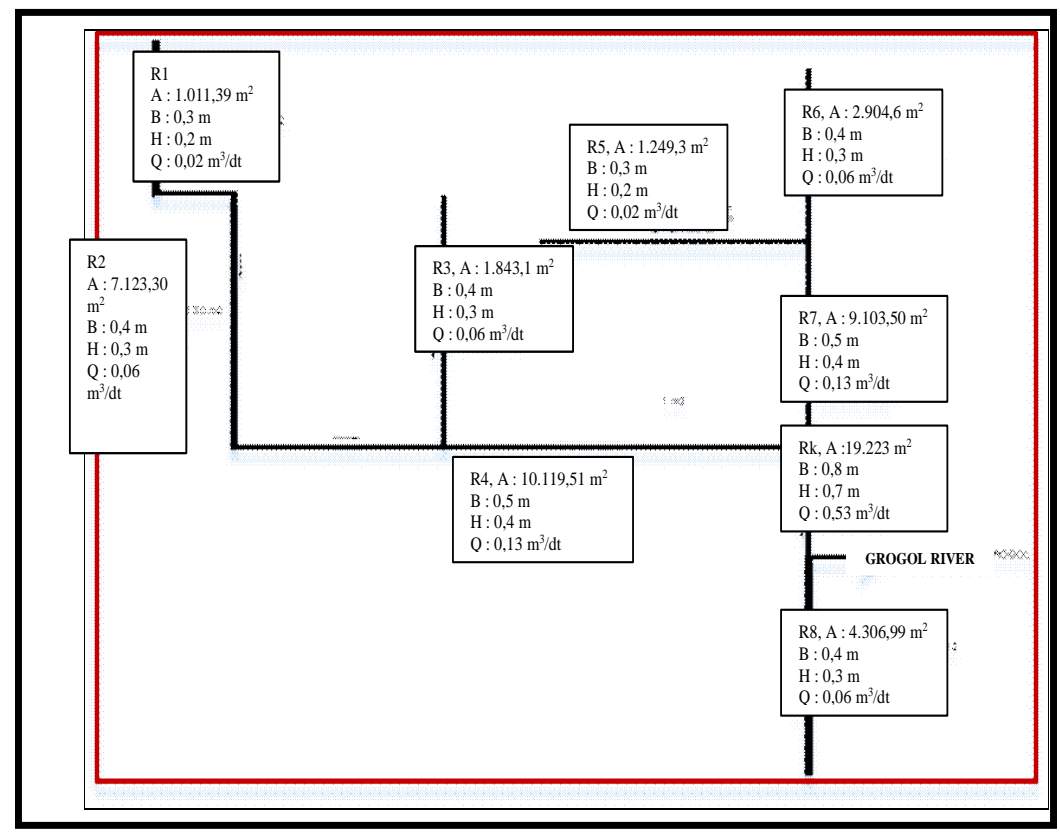

Figure 1. Internal Drainage Network Scheme of the Existing Area Study

The current situation at the study site is the rainwater runoff is directed to internal drainage and directly directed to Grogol River. Some recharge wells are located in basement and others are around existing buildings, but they can not be opened and can not be checked for maintenance.

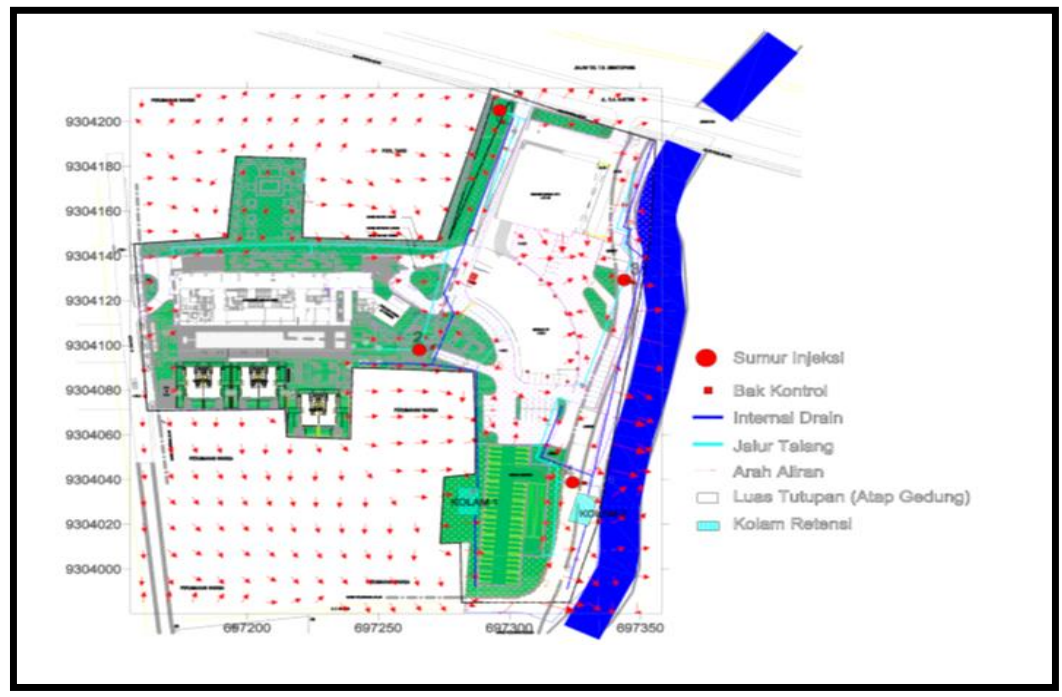

Explanation: Retention Pond; Onjection Well; - Manhole

Figure 2. Zero Runoff Concept Layout Plan (based on the choosen method) 


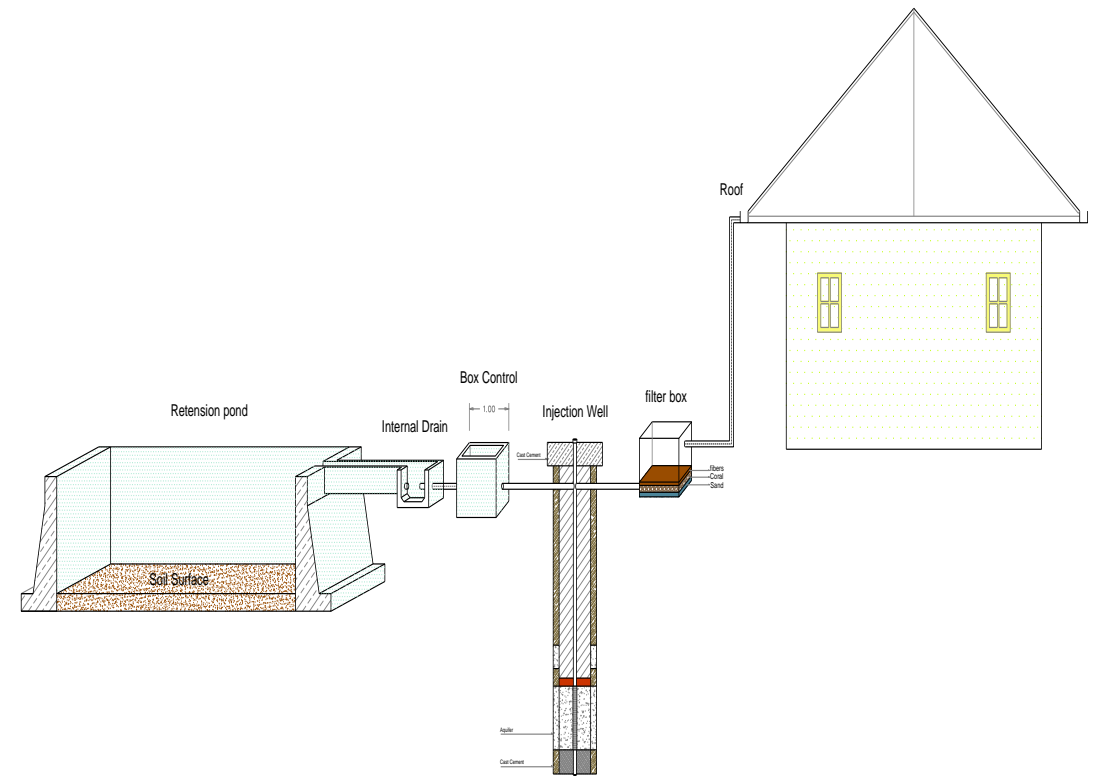

Figure 3. Zero Runoff Concept

(based on the choosen method)

Table 1. Comparison of Governor Regulation of Jakarta Capital City Administration method with Hydrological Analysis (Alternative III) and Indonesian National Standard Regulation (SNI) No. 032453-2002.

\begin{tabular}{|c|c|c|c|}
\hline No. & Comparison Descriptionn & Governor Regulation & $\begin{array}{l}\text { Hydrological Analysis (Alternative III) } \\
\text { and Indonesian National Standard } \\
\text { Regulation (SNI) No. 03-2453-2002 }\end{array}$ \\
\hline 1. & $\begin{array}{llcl}\begin{array}{l}\text { Recharge } \\
\text { calculation }\end{array} & \text { volume } & \text { based } & \text { on } \\
\end{array}$ & $978 \mathrm{~m}^{3}$ & $935,85 \mathrm{~m}^{3}$ \\
\hline 2. & Total recharge wells and dimension & $\begin{array}{l}\text { Dimension : Diameter } 3 \mathrm{~m} \times \text { Depth } 3 \mathrm{~m} . \\
\text { Number : } 22 \text { units }\end{array}$ & $\begin{array}{l}\text { Deep recharge wells : Diameter } 0,08 \mathrm{~m} \times \\
\text { depth } 13 \mathrm{~m} \text {. } \\
\text { Number : } 4 \text { units }\end{array}$ \\
\hline 3. & Retention Ponds (RP) & $\begin{array}{l}\text { Dimension : } 15 \mathrm{~m} \times 15,69 \mathrm{~m} \times 1,5 \mathrm{~m} \text {. } \\
\text { Volume : } 375,65 \mathrm{~m}^{3} \text {. } \\
\text { Obliged only for land with area of } 5.000 \mathrm{~m}^{2} \text {. } \\
\text { The depth and volume of the retention pond } \\
\text { is not determined (only the area achieved). }\end{array}$ & $\begin{array}{l}\text { Dimension : } \\
\text { Retention Pond I : } 12 \mathrm{~m} \times 12 \mathrm{~m} \times 3 \mathrm{~m} \\
\text { Retention Pond II : } 11 \mathrm{~m} \times 21,2 \mathrm{~m} \times 2 \mathrm{~m} \\
\text { Volume : } 394,63 \mathrm{~m}^{3} \text {. } \\
\text { For all land area based on runoff that } \\
\text { occurred at the site area. }\end{array}$ \\
\hline 4. & Conservation building overflow & $\begin{array}{l}\text { Discharged to the main drainage/ drainage } \\
\text { channel. }\end{array}$ & No discharge/ zero runoff \\
\hline 5. & $\begin{array}{l}\text { Structure and type of soil and soil } \\
\text { permeability value }\end{array}$ & Not calculated & $\begin{array}{l}\text { Calculated. } \\
\text { The effectiveness of conservation building } \\
\text { can be determined and obtained. }\end{array}$ \\
\hline 6. & Return period & Not mentioned. & Return period $5^{\text {th }}$ year \\
\hline 7. & Type of Land Cover/Land Surface & Not calculated & $\begin{array}{l}\text { The coefficient value (C) is calculated } \\
\text { based on the type of land cover/ soil } \\
\text { surface for the runoff discharge calculation }\end{array}$ \\
\hline 8. & $\begin{array}{l}\text { Calculation of time required by the } \\
\text { land to absorb runoff water in } \\
\text { conservation building. }\end{array}$ & Not calculated & $\begin{array}{l}\text { Calculated based on soil type related to soil } \\
\text { permeability coefficient value. Related to } \\
\text { the effectiveness of conservation building. }\end{array}$ \\
\hline 9. & $\begin{array}{l}\text { Network and Internal Drainage } \\
\text { Channel Dimensions. }\end{array}$ & Not calculated & $\begin{array}{l}\text { Calculated to obtain drainage channel } \\
\text { dimensions based on the volume of runoff } \\
\text { discharge, according to the contours of the } \\
\text { premises, and related to the planned water } \\
\text { management system. }\end{array}$ \\
\hline 10. & Advantages. & Bigger recharge volume & $\begin{array}{l}\text { - The calculation is based on the type of } \\
\text { soil and the condition of the premises. } \\
\text { - The selection of species and quantities, }\end{array}$ \\
\hline
\end{tabular}




\begin{tabular}{|c|c|c|c|}
\hline & & & $\begin{array}{l}\text { as well as age for conservation building } \\
\text { (recharge wells, retention ponds) are } \\
\text { very effective. } \\
\text { - Decision of water management system } \\
\text { adjusted to the condition of premises. } \\
\text { - The zero runoff concept can be } \\
\text { achieved. } \\
\text { - Lower budget for injection well. } \\
\text { - Fewer land requirements for } \\
\text { conservation area. }\end{array}$ \\
\hline 11. & Disadvantages. & $\begin{array}{l}\text { - The runoff discharge that can be recharge } \\
\text { is only based on roof covered area, } \\
\text { whereas the other covered area and the } \\
\text { type and condition of the land are not } \\
\text { calculated. } \\
\text { - The selection of the type and number of } \\
\text { conservation building (recharge wells, } \\
\text { retention ponds, detention ponds) can not } \\
\text { be effective because they are not adapted } \\
\text { to the type and condition of the site. } \\
\text { - Zero runoff has not been achieved, } \\
\text { because there is still possible overflow } \\
\text { from the conservation building out of the } \\
\text { premises. } \\
\text { - More budget for recharge well. } \\
\text { - Need more open space area for } \\
\text { conservation building. }\end{array}$ & $\begin{array}{l}\text { Requires a water management review that } \\
\text { comes with rainfall data and soil } \\
\text { investigation data. }\end{array}$ \\
\hline No. & Comparison Descriptionn & Governor Regulation & $\begin{array}{l}\text { Hydrological Analysis (Alternative III) } \\
\text { and Indonesian National Standard } \\
\text { Regulation (SNI) No. 03-2453-2002 }\end{array}$ \\
\hline 12. & Conservation Building Options & $\begin{array}{l}\text { Not adjusted to the type of soil and the } \\
\text { condition of the premises, so that its } \\
\text { effectiveness can not be achieved. }\end{array}$ & $\begin{array}{l}\text { Adjusted to the type of soil and the } \\
\text { condition of the premises, so that its } \\
\text { effectiveness can be achieved. }\end{array}$ \\
\hline 13. & Implementation on the field & Implementable & Implementable \\
\hline
\end{tabular}

\section{Conclusions}

The conclusions obtained from the results of the discussion are as follows: Each method has its own advantages and disadvantages, but in the research it is found that the result of calculation by Hydrological method and Indonesian National Standard Regulation (SNI) No. 03-2453-2002 has more advantages than its disadvantages compared with Governor Regulation of Jakarta Capital City Administration of method, where the calculation and result are more detailed and the zero runoff concept can be achieved, so as not to increase the load of Grogol River.

\section{References}

Arnelliya Fitri, Azura Ulfa. 2015. The Implementation of Zero Run Off and Agroforesty Concept Based on River Discharge in Belik Sub Watershed, Yogyakarta. Journal of Regional and City Planning Institute Teknologi Bandung, volume 26 No. 3. (Yogyakarta : Gadjah Mada University Indonesia).

Badan Standardisasi Nasional. 2001. Peraturan Standar Nasional Indonesia (SNI) 0324532002 tentang Tata Cara Perencanaan Teknik Sumur Resapan Air Hujan Untuk Lahan Pekarangan. Jakarta : Badan Standardisasi Nasional.

Christopher J. Wals.,Tim D. Fletcher. Matthew J. Burns., 2012. Urban Stormwater Runoff : A New Class of Environment Flow Problem. (United States of America. https://doi.org/10.1371/journal.pone.0045814).

Dinas Tata Air Provinsi DKI Jakarta. 2015. Data Teknis Kajian Air Tanah. Jakarta. 
Evangelos A. Baltas. 2009. Climate Change and Associated Implications for the Water Policy Framework in the Basin of Venetikos. International Journal of Water Resources Development volume 25. P 491 -506.

Gubernur Provinsi Daerah Khusus Ibukota Jakarta. 2013. Peraturan Gubernur Provinsi Daerah Khusus Ibukota Jakarta nomor 20 tahun 2013 tentang Sumur Resapan. Jakarta : Provinsi Daerah Khusus Ibukota Jakarta.

Gubernur Provinsi Daerah Khusus Ibukota Jakarta. 2013. Peraturan Gubernur Provinsi Daerah Khusus Ibukota Jakarta Nomor 43 tahun 2013 tentang Pelayanan Rekomendasi Peil Lantai Bangunan. Jakarta : Provinsi Daerah Khusus Ibukota Jakarta.

I. M. Faisal Civil Engineering, S. Parveen, M.R. Kabir. 2006. Sustainable Development through Groundwater Management : A Case Study on the Barind Tract. International Journal of Water Resources Development, volume 21. P 425 -435.

Jacinta A. Opara. 2016. (URP) Environmental Health Challenges and Sustainable Development in Nigeria: Implications for Policy and Management. International journal of Contemporary Research and Review, volume 7 No. 7.

Lizarraga - Mendiola L, Vazquez - Rodriguez. G, Blanco - Pinon . A, et. al. 2015. Estimating the Rainwater Potential per Household in an Urban Area: Case Study in Central Mexico. WATER Journal, volume 7 No. 9. P 4622 - 4637.

Osborne. J, Lambert. F, Groenendijk. M. et al. 2015. Reconciling Precipitation with Runoff: Observed Hydrological Change in the Midlatitudes. Journal of Hydrometeorology, volume 16 No. 6. P $2403-2420$.

S.R. Barick, B.K. Ratha. 2017. Hydrological Studies and Water Quality Analysis Around The Limestone Mining in the Hial Area of Bolangir District, Odisha for The Optimal Use And Sustainable Management of Available Water Resources. International journal of Contemporary Research and Review, volume 8 No. 7.

Tewodros Negash Kahsay, Onno Kuik, Roy Brouwer, Pieter van der Zaag. 2018. The Transboundary Impacts of Trade Liberalization and Climate Change on the Nile Basin Economies and Water Resource Availability. Water Resources Management Journal, Issue 3/ 2018.

Zhang. D, Gersberg. R, Wilhelm. C, et. al. 2009. Decentralized water management: Rainwater harvesting and greywater reuse in an urban area of Beijing, China. Urban Water Journal, volume 6 No. 5. P 375- 385. 